\title{
Profile of endoparasites in dairy cattle in the microregion of São João del-Rei, state of Minas Gerais, Brazil
}

\author{
[Perfil de endoparasitas em bovinos leiteiros na microrregião de São João del-Rei, \\ Minas Gerais, Brasil] \\ R.F. Henriques ${ }^{1}$, F.B. Pereira ${ }^{2}$, J.T. Paiva ${ }^{3}$, M.A. Silva ${ }^{4}$, R.M.P.S. Melo $^{4}$ \\ ${ }^{1}$ Aluna de pós-graduação - Universidade Federal de Mato Grosso do Sul - Campo Grande, MS \\ ${ }^{2}$ Universidade Federal de Minas Gerais - Belo Horizonte, MG \\ ${ }^{3}$ Universidade Federal de Viçosa - Viçosa, MG \\ ${ }^{4}$ Universidade Federal de São João del Rei - São João del-Rei, MG
}

\begin{abstract}
The present study provides the first evaluation of the endoparasite profile in dairy cattle from the microregion of São João del-Rei, Minas Gerais, Brazil, including seasonal variations in parasitic infections. Fecal samples were collected directly from rectum of 123 dairy cows and 160 calves on 15 farms. These were kept in insulated boxes and sent for immediate analysis. Using eggs per gram of feces (EPG) we found the following prevalences: Strongyloidea 43.5\%, Moniezia sp. $7.6 \%$ and both Strongyloides sp. and Trichuris spp. 2.2\%, in dairy cows. In calves, the prevalence was Strongyloidea 50.9\%, Moniezia sp. 5.6\% and Strongyloides sp. $1.9 \%$. The third-stage larvae recovered from coprocultures from cows and calves consisted mainly of Cooperia spp., Haemonchus spp. and Ostertagia spp. EPG counts were significantly higher in calves. Regarding seasonality, the EPG counts and prevalence of Moniezia sp. tended to be higher in the dry period, whereas those of Strongyloidea were higher in the rainy season. Evidence suggests that parasite control and prophylaxis were inadequately managed on the farms studied here. The present parasitological profile correlates with those found by other similar studies, indicating that the main problem is still the inadequate management of parasite control and prophylaxis by farmers.
\end{abstract}

Keywords: anthelmintics, diagnosis, epidemiology, helminths, ruminants

\section{RESUMO}

O presente estudo representa a primeira avaliação do perfil de endoparasitos em bovinos leiteiros da microrregião de São João del-Rei, Minas Gerais, Brasil, e das variações sazonais das infecções parasitárias. Foram avaliadas amostras fecais de 123 vacas e 160 bezerros de 15 propriedades rurais, coletadas diretamente do reto, mantidas em caixas térmicas isoladas e analisadas imediatamente. A contagem de ovos por grama de fezes $(O P G)$ revelou prevalências de 43,5\% de Strongyloidea, 7,6\% de Moniezia sp. e 2,2\% de Strongyloides sp. e Trichuris spp. em vacas leiteiras. As prevalências de OPG em bezerros foram 50,9\% de Strongyloidea, 5,6\% de Moniezia sp. e 1,9\% de Strongyloides sp. As larvas do terceiro estádio recuperadas de coproculturas de vacas e bezerros foram principalmente de Cooperia spp., Haemonchus spp. e Ostertagia spp. $O P G$ dos parasitos foram significativamente maiores em bezerros. Em relação à sazonalidade, OPG e a prevalência de Moniezia sp. tenderam a ser maiores durante a estação seca, enquanto OPG de Strongyloidea foram maiores na estação chuvosa. Com base nos resultados, é possível concluir que o manejo antiparasitário nas propriedades estudadas não é realizado de maneira plenamente satisfatória. $O$ presente perfil parasitológico se assemelha a outros encontrados em estudos semelhantes, indicando que o maior problema ainda é o manejo antiparasitário inadequado realizado nas propriedades de bovinos leiteiros.

Palavras-chave: anti-helmínticos, diagnóstico, epidemiologia, helmintos, ruminante

Recebido em 22 de abril de 2020

Aceito em 8 de setembro de 2020

E-mail: renata_henriques28@hotmail.com 


\section{Henriques et al.}

\section{INTRODUCTION}

Data from the Brazilian Institute for Geography and Statistics indicated that the total Brazilian cattle population was estimated to be around 218 million head in 2017 (Estatística..., 2018). Endoparasite infections may act directly and/or indirectly on herds and are responsible for considerable economic losses. They reduce weight gain, carcass yield and milk production, as well as increase mortality and expenditure on antiparasitic drugs (Charlier et al., 2014). The strategic management is crucial for treating gastrointestinal helminthiasis in cattle, because when anthelmintic drugs are correctly administrated, the profitability of the herd shows considerable improvement (Cezar et al., 2008). In this sense, evaluating the prevalence of such parasites is important for developing the adequate management.

The state of Minas Gerais is the largest producer of milk and dairy products in Brazil, with a mean output of 8.97 billion liters of milk per year, which represents $26.7 \%$ of the whole national production (Estastística..., 2018). The microregion of São João del-Rei is one of the strongest participants in this sector within the state (Pinto and Perobelli, 2016). However, the dairy cattle herd has been growing in other parts of Brazil, especially in the central-western and southern regions, and this reflects greater investments in production technology in these regions (Pinto and Perobelli, 2016). Milk is among the six most important products from the Brazilian farming industry, and it is a crucial generator of food and income for the population (Carvalho et al., 2013). Reduction of parasite infections in dairy cattle may improve milk production, consequently enabling yields of up to 63 liters/cow/year (Voort et al., 2014).

Endoparasites have an obligate relationship with their hosts, in which the host may suffer longterm losses (Gurgel-Gonçalves et al., 2007). Helminth infections in cattle are commonly present in the gastrointestinal tract and lungs; these parasites may disturb the animal's homeostasis and may lead to death in some cases (Charlier et al., 2014). It has been observed that some individuals are naturally more resistant to helminth infections than others, and nutritional status is known to exert a direct influence on this process (Houdijk, 2012). However, the dynamics of parasite resistance to anthelmintic drugs in cattle are not completely understood and the most appropriate chemical management remains unclear. This lack of knowledge results in cases of parasite resistance (Mello et al., 2006).

Several prophylactic measures have been adopted by cattle breeders to avoid parasite infections, especially those based on chemical treatments. However, this practice is often wrongly applied because breeders sometimes have insufficient knowledge of these procedures, which compromises the efficacy of the treatment (Souza et al., 2008; Pereira, 2011). Anthelmintic drugs are commonly administered to young calves, but older animals aged 24 to 30 months also exhibit frequent helminth infections (Bresciane et al., 2001; Antonello et al., 2010). Therefore, chemical treatments need to have a wider range (Bresciane et al., 2001; Antonello et al., 2010), even though some authors believe that cattle over the age of 18 months may be considered immunologically competent in relation to helminth infections, not requiring treatment (Bianchin et al., 2007).

One of the most important steps for an efficient prophylaxis and control of helminth infections in cattle is to take into account the particularities of the parasite fauna in each herd. The first step is record parasitological profiles. Currently, there are no studies evaluating the parasitological profile of dairy cattle in the microregion of São João del-Rei, state of Minas Gerais, Brazil. The present study aimed to evaluate the prevalence and abundance of gastrointestinal helminths infecting dairy cattle (cows and calves) on different farms in the microregion of São João del-Rei and assess their possible seasonal variations in order to obtain a complete parasitological profile.

\section{MATERIALS AND METHODS}

From January 2013 to March 2014, animals from 15 farms in the microregion of São João del-Rei were studied. This region is located in the southeastern part of the state of Minas Gerais, Brazil $\left(21^{\circ} 08^{\prime} 00^{\prime \prime} \mathrm{S}\right.$ and $44^{\circ} 15^{\prime} 40^{\prime \prime} \mathrm{W}$; at an altitude of around $898 \mathrm{~m}$ ), with a tropical highaltitude climate, according to the Köppen climate classification system, mean annual temperature of $19.2{ }^{\circ} \mathrm{C}$ (range: $3-38{ }^{\circ} \mathrm{C}$ ). The climate is characterized by two marked seasons: one, hot 
and humid; and the other, colder and dry. The municipalities associated with the number of farms are as follows: Coronel Xavier Chaves (n = 5), Lagoa Dourada $(n=1)$, Madre de Deus de Minas $(n=1)$ and São João del-Rei $(n=8)$.

Information on each farm relating to environmental features, antiparasitic treatments, cattle management, age and breed were assessed by a specific questionnaire, answered by the farmers. Data on seasonal characteristics of the study area, temperature, rainfall and relative humidity were obtained from the weather database for teaching and research (BDMEP) of the National Institute of Meteorology (INMET). These data had been recorded in the automated meteorological station of São João del-Rei (reference number A514; reference code OMM:86849). The dry season is from March to September, comprising autumn and winter, and is characterized by low temperatures and rainfall. The rainy season is from October to April, comprising the spring and summer, and is characterized by elevated temperatures and high rainfall.

Totals of 223 and 106 fecal samples were collected from dairy cows and calves, respectively, being 20 to 25 samples from each farm. Samples were collected directly from the rectal ampulla and individualized in identified plastic bags. Bags were kept in insulated boxes filled with ice and immediately sent for analysis at the Ecology Laboratory of the Department of Animal Science, Federal University of São João del-Rei (UFSJ), Brazil.

Eggs per gram of feces (EPG) were estimated using the McMaster technique (Gordon and Whitlock, 1939), with minor modifications as follows: four grams of feces were homogenized with $60 \mathrm{ml}$ of supersaturated glucose solution; this mixture was homogenized, filtered in sieve with gauze, transferred to the McMaster counting chambers using a Pasteur pipette and observed under an optical microscope. EPG was estimated as follows: total number of eggs counted in both McMaster chambers $\times 50$ (Ueno and Gonçalves, 1998).

From each farm studied, the two samples with highest EPG counts (one from cows and one from calves) were taken for coproculturing in order to obtain infective (third stage) larvae (L3) of nematodes. The coproculture was performed as described by Roberts and O'Sullivan (1950), using vermiculite as substrate. Third-stage larvae (L3) were identified as described by Ueno and Gonçalves (1998), and correlation values between L3 and EPG of Strongyloidea were determined.

Differences in the EPG between cows and calves and between dry and rainy seasons were evaluated using Poisson regression (Dohoo et al., 2003). The same differences, but for prevalence of parasite eggs were tested using logistic regression (Dohoo et al., 2003). Seasonal differences in EPG counts and prevalence of eggs were tested separately, for cows and calves. The odds ratio (OR) for each regression was calculated in order to evaluate the presence and nature of association between the dependent and the independent variable. These associations were defined as follows: $0<\mathrm{OR}<1$ indicated an antagonistic association; OR $=1$ indicated a lack of association; and OR > 1 indicated a synergic association (Dohoo et al. 2003).

The independent reference variables were the dry season and calves, according to each regression performed. The $95 \%$ confidence interval (CI) for each regression was estimated, and if the interval included the number 1.0, the model was considered invalid. The results from statistical tests were considered significant when $\mathrm{p}<0.05$, OR $\neq 1$ and 1 was not included in the CI all together. Parasite eggs that occurred during only one season and/or in only one age category were excluded from the statistical tests. All the analyses were performed using $\mathrm{R}$ ( $\mathrm{R}$ Core..., 2018).

\section{RESULTS}

All the animals evaluated were Girolando crossbreds, and the maximum age of calves was six months. The total areas of all farms were similar (i.e., mean of $50 \mathrm{ha}$ ), as well as the management system (i.e., semi-intensive, in which $100 \%$ of the cattle had daily access to pasture). The forage grass type in the pastures consisted mainly of Brachiaria. Antiparasite chemical treatment was used and similar on all the farms (i.e., mostly applied twice a year, consisting of ivermectin). 


\section{Henriques et al.}

The EPG counts revealed a total of 9,550 helminth eggs. Among these, eggs of Strongyloidea were the most abundant, representing $80.6 \%$ of the total, followed by eggs of Moniezia sp., Strongyloides sp. and Trichuris spp., accounting for $15.7 \%, 2.6 \%$ and $1.1 \%$, respectively. Strongyloidea-type eggs were present in samples from all the farms studied, whereas eggs of Moniezia sp. were found in samples from almost half of the farms (7/15) and those of Strongyloides sp. and Trichuris spp. were only found on two farms. Strongyloides sp. and Trichuris spp. eggs were only found during the rainy period, and those of Trichuris spp. were only found in fecal samples from cows (Table 1, 2 and 3$)$.

EPG counts for Strongyloidea, Strongyloides sp. and Moniezia sp. were higher among calves, but their prevalence was not statistically different between cows and calves. Eggs of Trichuris spp. occurred only in cows (Table 1, 2 and 3). Calves showed higher EPG counts of Strongyloidea and Moniezia sp. during the rainy season and higher prevalence of Strongyloidea in the same period (Table 2 and 3). EPG count of Strongyloidea in cows was higher during the rainy season, but that of Moniezia sp. and its prevalence were lower in the same period (Table 2 and 3). The L3 from both calves and cows, recovered after coproculture, were similar: most common genera of parasites were Cooperia, Ostertagia and Haemonchus; the least frequent were Bunostomum and Trichostrongylus (Table 4). The L3 profiles were also similar among the farms.

Table 1. Comparisons between eggs per gram of feces (EPG) counts of different parasites and their prevalence $(\%)$ in dairy cows and calves in the microregion of São João del-Rei, state of Minas Gerais, Brazil

\begin{tabular}{|c|c|c|c|c|c|}
\hline \multirow[t]{2}{*}{ Taxon } & \multicolumn{2}{|c|}{ Mean \pm standard deviation (range) } & \multicolumn{3}{|c|}{ Statistical tests } \\
\hline & $\begin{array}{c}\text { Calves } \\
(\mathrm{n}=106)\end{array}$ & $\begin{array}{c}\text { Cows } \\
(\mathrm{n}=223)\end{array}$ & $\mathrm{p}$ & $\begin{array}{l}\text { Odds } \\
\text { ratio }\end{array}$ & $\begin{array}{c}95 \% \text { confidence } \\
\text { interval }\end{array}$ \\
\hline \multirow{6}{*}{$\begin{array}{l}\text { Strongyloidea } \\
\text { Strongyloides } \\
\text { sp. } \\
\text { Trichuris spp. } \\
\text { Moniezia sp. }\end{array}$} & $574 \pm 1285(0-6950)$ & $76.7 \pm 137(0-750)$ & $<0.001$ & 7.5 & $7.4-7.6$ \\
\hline & $2.4 \pm 17.4(0-150)$ & $1.3 \pm 9.4(0-100)$ & $<0.001$ & 1.8 & $1.5-2.1$ \\
\hline & - & $1.6 \pm 11.0(0-100)$ & - & - & - \\
\hline & $24.5 \pm 150(0-1250)$ & $7.2 \pm 29.9(0-250)$ & $<0.001$ & 3.4 & $3.2-3.6$ \\
\hline & \multicolumn{2}{|c|}{ Prevalence $(\%)$} & \multicolumn{3}{|c|}{ Statistical tests } \\
\hline & $\begin{array}{c}\text { Calves } \\
(\mathrm{n}=106)\end{array}$ & $\begin{array}{c}\text { Cows } \\
(\mathrm{n}=223)\end{array}$ & $\mathrm{p}$ & $\begin{array}{l}\text { Odds } \\
\text { ratio }\end{array}$ & $\begin{array}{c}95 \% \text { confidence } \\
\text { interval }\end{array}$ \\
\hline \multirow{4}{*}{$\begin{array}{l}\text { Strongyloidea } \\
\text { Strongyloides } \\
\text { sp. } \\
\text { Trichuris spp. } \\
\text { Moniezia sp. }\end{array}$} & 50.9 & 43.5 & 0.2 & 1.34 & $0.85-2.1$ \\
\hline & 1.9 & 2.2 & 0.8 & 0.8 & $0.16-4.39$ \\
\hline & - & 2.2 & - & - & - \\
\hline & 5.6 & 7.6 & 0.5 & 0.7 & $0.3-1.9$ \\
\hline
\end{tabular}

\section{DISCUSSION}

Strongylid nematodes are one of the common taxa of parasites infecting the gastrointestinal tract of cattle in Brazil, mainly those trichostrongylids (Trichostrongyloidea sensu Taylor et al., 2015). Several studies corroborate this assertion and were mostly conducted in the southeastern region of the country (Araujo and Lima, 2005; Repossi Junior et al., 2006; Dias et al., 2007). The same studies indicated that Strongyloides and Trichuris occur less frequently, with lower prevalence. Similar results were observed in here. 
Table 2. Eggs per gram of feces (EPG) counts of different parasites in dairy cows and calves, compared between the rainy and dry seasons, in the microregion of São João del-Rei, state of Minas Gerais, Brazil

\begin{tabular}{|c|c|c|c|c|c|}
\hline \multirow[t]{3}{*}{ Taxon } & \multicolumn{5}{|c|}{ Calves $(n=106)$} \\
\hline & \multicolumn{2}{|c|}{ Mean \pm standard deviation (range) } & \multicolumn{3}{|c|}{ Statistical tests } \\
\hline & Rainy $(\mathrm{n}=83)$ & Dry $(n=23)$ & $\mathrm{p}$ & $\begin{array}{l}\text { Odds } \\
\text { ratio }\end{array}$ & $\begin{array}{c}95 \% \text { confidence } \\
\text { interval }\end{array}$ \\
\hline \multirow{4}{*}{$\begin{array}{l}\text { Strongyloidea } \\
\text { Strongyloides } \\
\text { sp. } \\
\text { Trichuris spp. } \\
\text { Moniezia sp. }\end{array}$} & $727.1 \pm 1415.7(0-6950)$ & $21.7 \pm 47.3(0-150)$ & $<0.001$ & 0.03 & $0.02-0.04$ \\
\hline & $3 \pm 19.7(0-150)$ & - & - & - & - \\
\hline & - & - & - & - & - \\
\hline & $28.9 \pm 169.1(0-1250)$ & $8.7 \pm 32.5(0-150)$ & $<0.001$ & 0.3 & $0.26-0.34$ \\
\hline \multirow{7}{*}{$\begin{array}{l}\text { Strongyloidea } \\
\text { Strongyloides } \\
\text { sp. } \\
\text { Trichuris spp. } \\
\text { Moniezia sp. }\end{array}$} & \multicolumn{5}{|c|}{ Cows $(n=223)$} \\
\hline & \multicolumn{2}{|c|}{ Mean \pm standard deviation (range) } & \multicolumn{3}{|c|}{ Statistical tests } \\
\hline & Rainy $(\mathrm{n}=118)$ & Dry $(n=105)$ & $\mathrm{p}$ & $\begin{array}{l}\text { Odds } \\
\text { ratio }\end{array}$ & $\begin{array}{c}95 \% \text { confidence } \\
\text { interval }\end{array}$ \\
\hline & $80.8 \pm 128.8(0-750)$ & $75.4 \pm 139.8(0-600)$ & $<0.001$ & 0.12 & $0.10-0.31$ \\
\hline & $1.8 \pm 10.7(0-100)$ & - & - & - & - \\
\hline & $2 \pm 12.6(0-100)$ & - & - & - & - \\
\hline & $5 \pm 26.9(0-200)$ & $14.4 \pm 37.5(0-250)$ & $<0.001$ & 2.9 & $2.63-3.20$ \\
\hline
\end{tabular}

Table 3. Prevalence (\%) of eggs of different parasites in dairy cows and calves, compared between the rainy and dry seasons, in the microregion of São João del-Rei, state of Minas Gerais, Brazil

\begin{tabular}{|c|c|c|c|c|c|c|c|c|c|c|}
\hline \multirow{3}{*}{ Taxon } & \multicolumn{5}{|c|}{ Calves $(n=106)$} & \multicolumn{5}{|c|}{ Cows $(n=223)$} \\
\hline & \multicolumn{2}{|c|}{$\begin{array}{c}\text { Prevalence } \\
(\%)\end{array}$} & \multicolumn{3}{|c|}{ Statistical tests } & \multicolumn{2}{|c|}{$\begin{array}{c}\text { Prevalence } \\
(\%)\end{array}$} & \multicolumn{3}{|c|}{ Statistical tests } \\
\hline & $\begin{array}{c}\text { Rainy } \\
(\mathrm{n}= \\
83)\end{array}$ & $\begin{array}{l}\text { Dry } \\
(\mathrm{n}= \\
23)\end{array}$ & $\mathrm{p}$ & $\begin{array}{l}\text { Odds } \\
\text { ratio }\end{array}$ & $\begin{array}{c}95 \% \\
\text { confidence } \\
\text { interval }\end{array}$ & $\begin{array}{c}\text { Rainy } \\
(\mathrm{n}= \\
118)\end{array}$ & $\begin{array}{l}\text { Dry } \\
(\mathrm{n}= \\
105)\end{array}$ & $\mathrm{P}$ & $\begin{array}{l}\text { Odds } \\
\text { ratio }\end{array}$ & $\begin{array}{c}95 \% \\
\text { confidence } \\
\text { interval }\end{array}$ \\
\hline Strongyloidea & 59.0 & 21.7 & 0.002 & 0.06 & $0.04-0.32$ & 43.3 & 42.2 & 0.9 & 1.03 & $0.55-1.95$ \\
\hline $\begin{array}{l}\text { Strongyloides } \\
\text { sp. }\end{array}$ & 2.4 & - & - & - & - & 2.9 & - & - & - & - \\
\hline Trichuris spp. & - & - & - & - & - & 2.9 & - & - & - & - \\
\hline Moniezia sp. & 4.8 & 8.7 & 0.5 & 2.0 & $0.32-10.97$ & 4.7 & 17.3 & 0.004 & 4.26 & $1.55-11.7$ \\
\hline
\end{tabular}

Table 4. Genera of Strongyloidea identified based on third stage (L3) infective larva, obtained from coprocultures of fecal samples from dairy cows and calves, in the microregion of São João del-Rei, state of Minas Gerais, Brazil, together with their percentages and conversions into eggs per gram of feces (EPG) counts

\begin{tabular}{lcccc}
\multicolumn{1}{c}{ Taxon } & \multicolumn{2}{c}{ Calves } & \multicolumn{3}{c}{ Cows } \\
\cline { 2 - 5 } & \% L3 & EPG & \% 3 & EPG \\
\hline Bunostomum & 3.5 & 240 & 3.7 & 28 \\
Cooperia & 24.1 & 16778 & 26.0 & 195 \\
Haemonchus & 20.7 & 1438 & 21.5 & 161 \\
Nematodirus & 6.9 & 479 & 10.1 & 76 \\
Oesophagostomum & 17.2 & 1198 & 12.1 & 91 \\
Ostertagia & 24.1 & 16778 & 18.5 & 139 \\
Trichostrongylus & 3.5 & 240 & 9.0 & 68 \\
\hline
\end{tabular}

Higher EPG counts were observed in calves, but parasite prevalence was similar between these and cows. These results may indicate high levels of parasite infective stages on the pastures, as well as inadequate management of cows favoring cross-infection in calves. In the present properties, farmers were keeping their whole herd together in the pasture for a daily period. 
Other explanation may be the development of cattle's immune response, which is premature in calves. Animals older than 18 months are less susceptible to parasite infections in the gastrointestinal tract, as a consequence of previous exposure (acquired immunity) and/or improved development of the immune system, which normally occurs between the $18^{\text {th }}$ and $24^{\text {th }}$ months (Guerreiro, 2009; Antonello et al., 2010). In this sense, calves from the present study were no older than six months. Similar results were also found by other authors (Guerreiro, 2009; Antonello et al., 2010; Pereira, 2011).

It should be mentioned that high prevalence and EPG counts in adult animals may reflect inefficient antiparasitic control and, in order to achieve efficiency nutritional status, immunocompetence, environmental features, periodicity and adequateness of prophylactic management need to be taken into account (Antonello et al., 2010). Therefore, strategic control may be suitable for calves and that selective more appropriate for cows (Guimarães et al., 2000; Gennari et al., 2002; Antonello et al., 2010). It is also always important to consider the regional traits related to the dynamics between the environment, parasite and host.

Despite the low EPG counts and prevalence of Strongyloides sp. found in the present study, it cannot be discarded that alternative infection methods, e.g. trans mammary and prenatal (Anderson, 2000; Taylor et al., 2015), may be contributing with maintenance of parasite infection in the herd. Even though the prevalence of Strongyloidea eggs was significantly higher only for calves during the rainy period, the EPG counts for both cows and calves were clearly higher during this season. The environmental humidity has a direct correlation with the viability and survival of eggs and larvae of Strongyloidea in the pasture, in which higher humidity during the rainy period favors the parasite infection (Morley and Donalds, 1980; Lima et al., 1985; Anderson, 2000).

This is particularly important for trichostrongylid nematodes, since they show relatively rapid development from egg to infective L3 (7-10 days normally) (Taylor et al., 2015). In this sense, trichostrongylids from cattle increase egglaying during the rainy period. It seems that the seasonal pattern observed here is common in this type of habitat and climate (Araujo and Lima, 2005). Unlike Strongylid nematodes, the cestode Moniezia sp. seemed to increase its egg (or proglottid)-laying and, consequently, prevalence during the dry season. This feature may be related to the parasite biology, in which the life cycle of Moniezia is heteroxenous and it uses oribatid mites as obligate intermediate hosts (Guerreiro, 2009).

Egg-laying and infection rates of this cestode are probably synchronic with the biological factors of mites, taking into account the pre-patent period and the development of the infective cysticercoid. Thus, Moniezia sp. is not as dependent on environmental humidity as are Strongylid nematodes; moreover, the eggs of this cestode are much more resistant to desiccation (Taylor et al., 2015).

EPG count is an important method for detecting gastrointestinal helminth infections in cattle. However, to identify the genera of nematodes, it is necessary to perform coproculturing, especially with eggs of Strongyloidea that are morphologically identical among genera (Bresciane et al., 2017). The present results showed high L3 percentages and consequent EPG counts of Cooperia spp., Haemonchus spp. and Ostertagia spp. These genera of trichostrongylids are very common in dairy cattle in Brazil (Dias et al., 2007; Santos et al., 2010; Silva et al., 2012). The high percentage of Cooperia spp. may be related to its high mobility in pastures as larva, and better resistance to desiccation; while that of Haemonchus spp. is due to its high prolificacy (Dias et al., 2007).

The genus Ostertagia, which is known to be common in temperate climates (Taylor et al., 2015), was frequent in the present coprocultures, contrasting with previous results observed in a similar environment to that in the present study (Dias et al., 2007). Our observations are alarming, since Ostertagia is a genus of great veterinary importance, because these parasites can damage the gastric glands of the abomasum, causing digestive disorders (Taylor et al., 2015).

Most of the L 3 recovered in the present study are commonly reported in cattle (Dias et al., 2007; Santos et al., 2010; Silva et al., 2012). The pathogenesis caused by the adult stage of these strongylid nematodes, infecting the 
gastrointestinal tract of cattle in Brazil remain very important, because they usually occur in concurrent infections and are responsible for several physiological alterations, including the severe condition of parasitic gastroenteritis syndrome (Taylor et al., 2015). This syndrome usually results in severe production losses and may become widespread in the herd if not treated correctly (Taylor et al., 2015).

It was interesting that the L3 profile observed here was similar to that found in an organic management system free from anthelmintic drugs (Silva et al., 2012). The methods for controlling parasites in cattle that were applied on the farms of the present study were primarily based on chemical treatment. This suggests that the parasites are highly adaptable to the climatic/environmental conditions found in the diverse regions of Brazil, with widespread distribution in pastures and possible resistance to some anthelmintics.

On some of the present farms, some animals were highly parasitized, suggesting an inefficient management and control. This is concerning since all the farms were using similar antiparasitic strategies. Amongst the most problematic issues favoring parasite infections here were the lack of dunghills, absence of strategic treatment of the herd and lack of orientation on the choice of chemicals and the correct period for their application. The present parasitological profile was similar to that found in other regions of Brazil where dairy cattle are farmed, in which calves have high parasite burdens than cows as a consequence of immune development.

Moreover, seasonal influence was mainly noted for trichostrongylid nematodes that remain more time directly on the external environment as larva and, consequently, are more susceptible to climatic fluctuations. Nematodes belonging to the Strongyloidea were also very prevalent and abundant, which correlates with the inefficient parasitological management and prophylaxis practiced by the present farmers. Our results represent the first contribution for the knowledge of the parasite fauna infection dairy cattle in the microregion of São João del-Rei, providing important basis for further understanding of the subject in the referred region.

\section{REFERENCES}

ANDERSON, R.C. Nematodes parasites of vertebrates: their development and transmission. Wallingford: CABI Publishing, 2000. 672p.

ANTONELLO, A.M.; CEZAR, A.S.; SANGIONI, L.A.; VOGEL, F.S.F. Contagens de ovos por grama de fezes para o controle antihelmíntico em bovinos de leite de diferentes faixas etárias. Ciênc. Rural, v.40, p.1227-1230, 2010.

ARAUJO, R.N.; LIMA, W.S. Infecções helmínticas em um rebanho leiteiro na Região Campo das Vertentes de Minas Gerais. Arq. Bras. Med. Vet. Zootec., v.57, p.186-193, 2005.

BIANCHIN, I.; CATTO, J.B.; KICHEL, A.N. et al. The effect of the control of endo and ectoparasites on the weight gains in crossbred cattle (Bos taurus x Bos indicus) in the central region of Brazil. Trop. Anim. Health Prod., v.39, p.287-296, 2007.

BRESCIANE， K.D.S.; COELHO, W.M.D.; GOMES, J.F. et al. Aspects of epidemiology and control of gastrointestinal nematodes in sheep and cattle - approaches for its sustainability. Rev. Cienc. Agrar., v.40, p.664-669, 2017.

BRESCIANE, K.D.S.; NASCIMENTO, A.A.; COSTA, A.J. et al. Freqüência e intensidade parasitária de helmintos gastrintestinais em bovinos abatidos em frigorífico da região noroeste do Estado de São Paulo, SP, Brasil. Semin. Ciênc. Agrár., v.22, p.93-97, 2001.

CARVALHO, L.A.; NOVAES, L.P.; MARTINS, C.E. et al. Sistema de produção de leite (Cerrado): importância econômica. 2013 Available in: http://sistemasdeproducao.cnptia.embrapa.br/Fon tesHTML/Leite/LeiteCerrado/importancia.html.

Accessed in: 18 Oct. 2018.

CEZAR, A.S.; CATTO, J.B.; BIANCHIN, I. Controle alternativo de nematódeos gastrintestinais dos ruminantes: atualidade e perspectivas. Cienc. Rural, v.38, p.2083-2091, 2008. 
CHARLIER, J.; VOORT, M.V.D.; KENYON, F. et al. Chasing helminths and their economic impact on farmed ruminants. Trends Parasitol., v.30, p.361-367, 2014.

DIAS, A.S.; ARAÚJO, J.V.; CAMPOS, A.K. et al. Relação entre larvas recuperadas da pastagem e contagem de ovos por grama de fezes (OPG) de nematóides gastrintestinais de bovinos na microrregião de Viçosa, Minas Gerais. Rev. Bras. Parasitol. Vet., v.16, p.33-36, 2007.

DOHOO, I.; MARTIN, W.; STRYHN, H. Veterinary epidemiologic research. Charlottetown: University of Prince Edward, 2003.

ESTATÍSTICA da produção pecuária. Rio de Janeiro: IBGE, 2018. Disponível em: https://biblioteca.ibge.gov.br/visualizacao/period icos/2380/epp_2018_2tri.pdf. Acessado em: 18 out. 2019.

GENNARI, S.M.; BLASQUES. L.S.; RODRIGUES, A.A.R. et al. Determinação da contagem de ovos de nematódeos no período peri-parto em vacas. Braz. J. Vet. Res. Anim. Sci., v.39, p.32-37, 2002.

GORDON, H.M.; WHITLOCK, H.V. A new technique for couting nematodes eggs in sheep faeces. J. Coun. Sci. Ind. Res. Aust., v.12, p.5052, 1939.

GUERREIRO, C.M.C. Influência do maneio na prevalência de parasitoses gastrointestinais em pequenos ruminantes: estudo comparativo entre a região do Alentejo e a região de Andaluzia. 2009. 135f. Dissertação (Mestrado em Medicina Veterinária) - Universidade Técnica de Lisboa, Lisboa, POR.

GUIMARÃES, M.P.; RIBEIRO, M.F.; FACURI-FILHO, E.J.; LIMA, W.S. Strategic control of gastrointestinal nematodes in dairy calves in Florestal, Minas Gerais, Brazil. Vet. Res. Commun., v.24, p.31-38, 2000.

GURGEL-GONÇALVES, R.; SOUZA, T.T.C.M.; COSTA NETO, E.M.; CUBA, C.A.C. O que é um parasito? Uma análise etimológica e semântica do termo parasito em diferentes idiomas. Acta Sci. Hum. Soc. Sci., v.29, p.151$161,2007$.
HOUDIJK, J.G.M. Differential effects of protein and energy scarcity on resistance to nematode parasites. Small Ruminant Res., v.103, p.41-49, 2012.

LIMA, W.S.; GUIMARÃES, M.P.; LEITE, A.C.R. Custo benefício de diferentes dosificações anti-helmínticas em relação ao ganho de peso de bezerros de corte. Pesqui. Agropecu. Bras., v.20, p.1333-1335, 1985.

MELLO, M.H.A.; DEPNER, R.; MOLENTO, M.B.; FERREIRA, J.J. Resistência lateral às macrolactonas em nematodas de bovinos. Arch. Vet. Sci., v.11, p.8-12, 2006.

MORLEY, F.H.W.; DONALD, A.D. Farm management and systems of helminth control. Vet. Parasitol., v.6, p.105-134, 1980.

PEREIRA, J.R. Práticas de controle e prevalência de helmintos gastrintestinais parasitos de bovinos leiteiros em Pindamonhangaba, São Paulo, Brasil. Rev. Ciênc. Agrovet., v.10, p.16-22, 2011.

PINTO, D.G.; PEROBELLI, F.S. Determinantes do crescimento da pecuária de leite em Minas Gerais: uma análise para o período de 2005 a 2014. Reflesões Econôm., v.1, p.44-67, 2016.

R CORE Team. R: a language and environment for statistical computing. Viena: R Foundation for Statistical Computing; 2018. Avialalble in: <https://www.R-project.org/>. Accessed in: 15 Sep. 2019.

REPOSSI JUNIOR, P.F.; BARCELLOS, M.P.; TRIVILIN, L.O. et al. Prevalência e controle das parasitoses gastrintestinais em bezerros de propriedades leiteiras no município de Alegre, Espírito Santo. Rev. Bras. Parasitol. Vet., v.15, p.147-150, 2006.

ROBERTS, F.H.S.; O'SULLIVAN, J.P. Methods for eggs counts and larval cultures for strongyles infesting gastrointestinal tract of cattle. Aust. J. Agric. Res., v.1, p.99-102, 1950.

SANTOS, T.R.; LOPES, W.D.Z.; BUZULINI, C. et al. Helminth fauna of bovines from the Central-Western region, Minas Gerais State, Brazil. Cienc. Rural, v.40, p.934-938, 2010. 
SILVA, J.B.; RANGEL, C.P.; FONSECA, A.H.; SOARES, J.P.G. Gastrointestinal helminthes in calves and cows in a organic milk production system. Rev. Bras. Parasitol. Vet., v.21, p.287291, 2012.

SOUZA, A.P.; RAMOS, C.I.; BELLATO, V. et al. Resistência de helmintos gastrintestinais de bovinos a anti-helmínticos no Planalto Catarinense. Cienc. Rural, v.38, p.1363-1367, 2008.

TAYLOR, M.A.; COOP, R.L.; WALL, R.L. Veterinary parasitology. 4.ed. Oxford: Wiley Blackwell, 2015. 1032p.
UENO, H.; GONÇALVES, P.C. Manual para diagnóstico das helmintoses de ruminantes. 2.ed. Tokyo: Japan International Cooperration Agency, 1998. 176p.

VOORT, M.V.D.; MEENSEL, J.V.; LAUWERE, L. et al. A stochastic frontier approach to study the relationship between gastrointestinal nematode infections and technical efficiency of dairy farms. J. Dairy Sci., v.97, p.3498-3508, 2014. 